\title{
Preparation of Novel Complex Nano-Structured Gold Catalyst Au@TiO2/MCM-22, Characterization and Remarkably Catalytic Performance for Cyclohexane Oxidation
}

\section{Jiaqi Si, Lin Li, Yanji Zhang, Ji-Cheng Zhou*, Wenbing Ouyang}

Key Laboratory of Green Catalysis and Reaction Engineering, Department of Education, College of Chemical Engineering, Xiangtan University, Xiangtan, China

Email: *zhoujicheng@sohu.com

How to cite this paper: Si, J.Q., Li, L., Zhang, Y.J., Zhou, J.C. and Ouyang, W.B. (2017) Preparation of Novel Complex NanoStructured Gold Catalyst Au@ $\mathrm{TiO}_{2} / \mathrm{MCM}$ 22, Characterization and Remarkably Catalytic Performance for Cyclohexane Oxidation. Modern Research in Catalysis, 6, 1529.

http://dx.doi.org/10.4236/mrc.2017.61002

Received: September 13, 2016

Accepted: January 9, 2017

Published: January 12, 2017

Copyright $(9) 2017$ by authors and Scientific Research Publishing Inc. This work is licensed under the Creative Commons Attribution International License (CC BY 4.0).

http://creativecommons.org/licenses/by/4.0/

\begin{abstract}
A novel complex nano-structured $\mathrm{Au} @ \mathrm{TiO}_{2}$ gold catalyst has been prepared. Au precursor could be transformed into $\mathrm{Au} @ \mathrm{TiO}_{2} / \mathrm{MCM}-22$ with the complex nano-structured using two different methods. Samples were characterized by XRD, FT-IR, UV-vis, TEM, ICP-AES and $\mathrm{N}_{2}$ adsorption-desorption. It is found that gold was anchored on the $\mathrm{TiO}_{2} / \mathrm{MCM}-22$ as small size and uniform particles with the average diameters in the range of $5-9 \mathrm{~nm}$. Catalytic results show that such nano-gold catalysts display excellent catalytic performance for cyclohexane oxidation. Au@ $@ \mathrm{TiO}_{2} / \mathrm{MCM}-22$ catalyst with the gold content of $0.5 \mathrm{wt} \%$ exhibits extremely exceptionally catalytic activity (12.81\%) and high turnover frequency $\left(52,121 \mathrm{~h}^{-1}\right)$, which may be ascribed to the synergistic effects of $\mathrm{Au}$ and $\mathrm{TiO}_{2}$ in the complex nano-structured catalyst $\mathrm{Au} @ \mathrm{TiO}_{2} /$ MCM-22. Because of the strong metal support interaction, aggregation of active sites (Au nanoparticles) during the oxidation reaction is effectively prohibited and the catalytic activity is essentially retained.
\end{abstract}

\section{Keywords}

Complex Nano-Structured Catalyst, Photocatalytic Reduction Method, $\mathrm{Au} @ \mathrm{TiO}_{2} / \mathrm{MCM}-22$, Gold Nanoparticles, Cyclohexane Oxidation

\section{Introduction}

The popular of nanoscience has exploded within the last two decades, mainly because new nano-synthesis processes have led to a wealth of novel nanostruc- 
tures with adjustable size and shape parameters, leaving researchers with extraordinary control over their chemical properties. Metal-oxide hybrid nanoparticles are quite interesting and popular among novel nanostructures [1] [2]. The materials systems are expanded from single-component nanoparticles to hybrid multicomponent heteronanostructures which integrate discrete domains of different compositions within one hybrid nanostructured entity [3] [4] [5]. Metal-oxide hybrid nanoparticles represent an important class of multicomponent nano-systems that may exhibit not only a combination of properties from the individual components but also further enhanced property and even new synergistic properties which arise essentially from the nanoscale interactions between the disparate metal and oxide components [6]. Two fundamental explanations of interaction between metal-oxide are proposed, so-called interfacial charge redistribution-electronic interaction [7] [8] and interfacial atom transport-chemical interaction [9] [10]. Furthermore, such nanoparticles defined by a diameter of $1-10 \mathrm{~nm}$, are creating a new category of materials, which is different either from conventional bulk materials or from atoms, the smallest units of matter [11] [12]. Thus, oxide supporting with ultrafine metal nanoparticles have tremendous prospects.

Tauster et al. [13] proposed the strong metal-support interaction (SMSI) firstly in 1978 to explain the suppression of $\mathrm{H}_{2}$ and $\mathrm{CO}$ chemisorption capacity of metal cluster on $\mathrm{TiO}_{2}$ chemically reduced at high temperatures. Since then, a large number of researches in catalysis have been reported, and they have extensively demonstrated that the SMSI in supported group VIII metal plays a prominent role in catalytic performances [14] [15]. The SMSI states are mainly influenced by two factors: geometric and electronic. The geometric factor is due to encapsulation, which results from a physical covering of metal particles by a thin layer of reduced oxide support (e.g. $\mathrm{TiO}_{2}, \mathrm{~V}_{2} \mathrm{O}_{5}, \mathrm{SiO}_{2}$ and $\mathrm{Al}_{2} \mathrm{O}_{3}$ ) [16]. The electronic factor is determined by a perturbation (for example, a charge transfer between the metal and the oxide) of the electronic of the metal catalyst [17]. It is reported that the metals with high surface energy such as Pt and Pd are more likely to be encapsulated than those with low surface energy (e.g. $\mathrm{Au}$ and $\mathrm{Cu}$ ) [18].

The selective oxidation of cyclohexane to cyclohexanone and cyclohexanol is one of the most compelling researches in the field of catalytic chemical research, for the oxidation products (cyclohexanone and cyclohexanol) are very important chemical raw materials and intermediates, mainly for the production of adipic acid and caprolactam, which is the monomer of nylon-6 and nylon-66, respectively [19] [20]. Metal-oxide hybrid nanoparticles have been applied to cyclohexane oxidation in the literature. $\mathrm{Zhu}$ et al. [21] [22] [23] prepared $\mathrm{Au} / \mathrm{Al}_{2} \mathrm{O}_{3}$, $\mathrm{Au} / \mathrm{Al}_{2} \mathrm{O}_{3} / \mathrm{SiO}_{2}$ and $\mathrm{Au} / \mathrm{TiO}_{2} / \mathrm{SiO}_{2}$ catalysts by deposition precipitation method, and the good results of cyclohexane oxidation suggested that gold supported on the oxides might be superior catalysts. However, turnover frequency (TOF) of these catalysts is relatively low and reaction time is long.

Herein, we report a novel complex nano-structured $\mathrm{Au} @ \mathrm{TiO}_{2}$ catalyst pre- 
pared by photocatalytic reduction method and deposition precipitation method. In particular, Au nanoparticles with a diameter around $7 \mathrm{~nm}$ are well-decorated on the $\mathrm{TiO}_{2} / \mathrm{MCM}-22$ surface. The as-synthesized $\mathrm{Au} @ \mathrm{TiO}_{2} / \mathrm{MCM}-22$ nanocomposites are used for cyclohexane oxidation. For the synergistic effects of $\mathrm{Au}$ and $\mathrm{TiO}_{2}$ in the nano-Au@TiO 2 hybrid structure, $\mathrm{Au} @ \mathrm{TiO}_{2} / \mathrm{MCM}-22$ has enhanced catalytic activity remarkably for oxidation of cyclohexane. The recyclability tests display that the as-synthesized catalyst has strongly chemical and mechanical stability. Supported noble metal nanoparticles catalysts ( $\mathrm{Pd}, \mathrm{Pt}, \mathrm{Ru}$, etc.) with nano-Me@ $\mathrm{TiO}_{2}$ complex structure could be also prepared and applied into different reaction system.

\section{Experimental}

\subsection{Catalyst Preparation}

\subsubsection{Preparation of $\mathrm{TiO}_{2} / \mathrm{MCM}-22$ by Sol-Gel}

The MCM-22, referring to Wang et al. [24] using hexamethyleneimine (HMI) as template, was synthesized. A certain amount of MCM-22 (1.00 g) and $5 \mathrm{~mL}$ of tetrabutylammonium titanate (TBOT) were dissolved together in ethanol (15 $\mathrm{mL}$ ), and the solution was stirred at $300 \mathrm{rpm}$ at $293 \mathrm{~K}$ for $12 \mathrm{~h}$. Then a small amount of $\mathrm{HNO}_{3}$ was added under stirring. After aging for $24 \mathrm{~h}$ at ambient temperature and drying for $24 \mathrm{~h}$ at $363 \mathrm{~K}$, the resulting mixture was calcined for $3 \mathrm{~h}$ at $823 \mathrm{~K}$ thermostatically. According to principles of the spontaneous monolayer distribution, metal oxide would disperse on the support with a state of the spontaneous monolayer distribution, when the content of metal oxide is less than a certain threshold. Thus, the $\mathrm{TiO}_{2}$ loaded on the MCM-22 could form a monolayer or multilayers, which could be achieved by adjusting the loading of $\mathrm{TiO}_{2}$.

\subsubsection{Preparation of $\mathrm{Au} @ \mathrm{TiO}_{2} / \mathrm{MCM}-22$ by Photocatalytic Reduction Method}

Typically, 0.5\% Au@ $\mathrm{TiO}_{2} / \mathrm{MCM}-22$ (PR) catalyst were prepared as follow: the prepared $\mathrm{TiO}_{2} / \mathrm{MCM}-22$ samples $(1.00 \mathrm{~g}$ ) were dispersed in $100 \mathrm{~mL}$ distilled water and treated by ultrasonic agitation for $10 \mathrm{~min}$. The slurry was transferred into the reactor, and distilled water was added to dilute the mixture to $90 \mathrm{~mL}$ and stirred for $1 \mathrm{~h}$. Subsequently, $\mathrm{HAuCl}_{4} \cdot 4 \mathrm{H}_{2} \mathrm{O}(0.1050 \mathrm{~g})$ were added. Two drops of $\mathrm{HNO}_{3}$ solution were added to adjust the $\mathrm{pH}$ to 3; the suspension was irradiated with a $15 \mathrm{~W}$ UV lamp for $4 \mathrm{~h}$. Finally, the samples were separated by filtration, washed several times by distilled water, dried for $4 \mathrm{~h}$ at $355 \mathrm{~K}$. The obtained material was denoted by $\mathrm{Au} @ \mathrm{TiO}_{2} / \mathrm{MCM}-22$ (PR).

\subsubsection{Preparation of $\mathrm{Au} @ \mathrm{TiO}_{2} / \mathrm{MCM}-22$ by Deposition Precipitation Method}

Typically, 0.5\% $\mathrm{Au} @ \mathrm{TiO}_{2} / \mathrm{MCM}-22$ (DP) catalyst were prepared as follow: $\mathrm{HAuCl}_{4} \cdot 4 \mathrm{H}_{2} \mathrm{O}(0.1050 \mathrm{~g})$ were added into the mixer of $\mathrm{TiO}_{2} / \mathrm{MCM}-22(1.00 \mathrm{~g})$ and distilled water $(90 \mathrm{~mL})$, which was mixed uniformly by ultrasonic. After adjusting $\mathrm{pH}$ to 9.0 with $\mathrm{NaOH}$ solution, the solution was stirred for $4 \mathrm{~h}$ in dark. 
The suspension was filtrated, washed by distilled water, dried at $255 \mathrm{~K}$, and calcined at $523 \mathrm{~K}$ for $6 \mathrm{~h}$. The obtained material was denoted by $\mathrm{Au} @ \mathrm{TiO}_{2} / \mathrm{MCM}-$ 22 (DP).

\subsection{Catalyst Characterization}

The nitrogen cryogenic adsorption isotherms were obtained on an AUTOSORB1-MP-type physical adsorption instrument. Specific surface area measured by BET method, pore size distribution and pore volume calculated by the BJH method. The chemical compositions of the samples were determined by ICP-AES (IRIS Intrepid II XSP). Fourier transform infrared (FT-IR) spectroscopy measurement was recorded on Nicolet 380 equipment, using $\mathrm{KBr}$ pellet method. $\mathrm{X}$-ray Diffraction (XRD) patterns were collected on a D/max-3c diffract meter operated at $100 \mathrm{~mA}$ and $40 \mathrm{kV}$. The step size was 0.02 degree and the step time was one min. Transmission electron microscopy (TEM) images were obtained on a JEM-2010 at $160 \mathrm{kv}$. UV-Vis spectroscopy measurement was recorded on Japan UV-2550 equipment.

\subsection{Catalytic Reaction Experiments}

In a typical oxidation reaction, $100 \mathrm{~mL}$ cyclohexane, $0.08 \mathrm{~g}$ catalyst and $0.4 \mathrm{~g}$ tert-butyl hydrogen peroxide (TBHP) as initiator were added in a $300 \mathrm{~mL}$ autoclave reactor. The reactor was heated to $423 \mathrm{~K}$ and the $\mathrm{O}_{2}$ pressure was adjusted to $1.0 \mathrm{MPa}$. After $1.0 \mathrm{~h}$ of reaction, the liquid was extracted from the autoclave and the catalysts were separated. The product of cyclohexanol and cyclohexane were analyzed by gas chromatograph (Agilent $6890 \mathrm{~N}$ ) with internal standard method using chlorobenzene as the standard substance. The concentration of cyclohexyl hydroperoxide (CHHP) was analyzed by iodometric, and the acids and esters were determined by acid-base titration.

\section{Results and Discussion}

\subsection{Characterization}

\subsection{1. $\mathrm{N}_{2}$ Adsorption-Desorption Isotherms}

Table 1 shows the $\mathrm{N}_{2}$ adsorption-desorption isotherms of the as-prepared samples. A dramatic decrease of the specific surface area can be discerned after doping of $\mathrm{TiO}_{2}$, while there are only mild decreases in pore volume. This can be the reason of that $\mathrm{TiO}_{2}$ is layered dispersion in the bore wall of the MCM-22 hole rather than a cluster state. Moreover, after loading gold, the pore size of $\mathrm{TiO}_{2} / \mathrm{MCM}$ 22 is decreased slightly. This is mainly because a part of pores of $\mathrm{TiO}_{2} / \mathrm{MCM}-22$ may be blocked by the depositing of gold onto the substrate [25] [26].

\subsubsection{ICP-AES Analysis}

The Au loading efficiency of prepared samples is revealed by ICP-AES in Table 2. It is evident that modifying MCM-22 with $\mathrm{TiO}_{2}$ is useful to improve the loading of $\mathrm{Au}$ indeed (Table 2, Entry 1 and 2), and this is consistent with $\mathrm{Xu}$ et al. [22]. Entry 2 and 5 in Table 2 show that photocatalytic reduction method can 
Table 1. Textural properties obtained from $\mathrm{N}_{2}$ physisorption.

\begin{tabular}{cccc}
\hline Sample & $\mathrm{S}_{\mathrm{BET}} / \mathrm{m}^{2} \cdot \mathrm{g}^{-1}$ & $\mathrm{~V}_{\mathrm{BJH}} / \mathrm{cm}^{3} \cdot \mathrm{g}^{-1}$ & $\mathrm{D}_{\text {BJH }}^{\mathrm{a}} / \mathrm{nm}$ \\
\hline $\mathrm{MCM}-22$ & 352 & 0.24 & 1.25 \\
$\mathrm{TiO}_{2} / \mathrm{MCM}-22$ & 275 & 0.22 & 1.25 \\
$\mathrm{Au} @ \mathrm{TiO}_{2} / \mathrm{MCM}-22(\mathrm{PR})$ & 273 & 0.22 & 1.20 \\
\hline
\end{tabular}

${ }^{\mathrm{a}}$ Calculated from the adsorption branch of the nitrogen adsorption and desorption isotherms. Au: $0.5 \mathrm{wt} \%$.

Table 2. Loading efficiency of Au nanoparticles under different conditions.

\begin{tabular}{ccccccc}
\hline Entry & Catalysts & $\begin{array}{c}\text { Illumination } \\
\text { time } \\
(\mathrm{h})\end{array}$ & $\begin{array}{c}\mathrm{Nu} \text { (winal } \\
\text { (wt\%) }\end{array}$ & $\begin{array}{c}\text { Actual } \mathrm{Au} \\
(\mathrm{wt} \%)\end{array}$ & $\begin{array}{c}\mathrm{m} \\
\text { (Catalyst)/g }\end{array}$ & $\begin{array}{c}\text { Loading } \\
\text { efficiency }\end{array}$ \\
\hline 1 & $\mathrm{Au} / \mathrm{MCM}-22$ & 4 & 0.5 & 0.21 & 0.843 & $35.4 \%$ \\
2 & $\mathrm{Au} @ \mathrm{TiO}_{2} / \mathrm{MCM}-22(\mathrm{DP})$ & 4 & 0.5 & 0.32 & 0.864 & $55.3 \%$ \\
3 & $\mathrm{Au} @ \mathrm{TiO}_{2} / \mathrm{MCM}-22(\mathrm{PR})$ & 4 & 0.1 & 0.14 & 0.708 & $99.1 \%$ \\
4 & $\mathrm{Au} @ \mathrm{TiO}_{2} / \mathrm{MCM}-22(\mathrm{PR})$ & 4 & 0.2 & 0.24 & 0.845 & $101.4 \%$ \\
5 & $\mathrm{Au} @ \mathrm{TiO}_{2} / \mathrm{MCM}-22(\mathrm{PR})$ & 4 & 0.5 & 0.46 & 0.909 & $83.6 \%$ \\
6 & $\mathrm{Au} @ \mathrm{TiO}_{2} / \mathrm{MCM}-22(\mathrm{PR})$ & 2 & 1.0 & 0.62 & 0.820 & $50.8 \%$ \\
7 & $\mathrm{Au} @ \mathrm{TiO}_{2} / \mathrm{MCM}-22(\mathrm{PR})$ & 4 & 1.0 & 0.82 & 0.861 & $70.8 \%$ \\
8 & $\mathrm{Au} @ \mathrm{TiO}_{2} / \mathrm{MCM}-22(\mathrm{PR})$ & 6 & 1.0 & 1.13 & 0.841 & $95.0 \%$ \\
9 & $\mathrm{Au} @ \mathrm{TiO}_{2} / \mathrm{MCM}-22(\mathrm{PR})^{\mathrm{a}}$ & 4 & 0.5 & 0.46 & 0.910 & $83.7 \%$ \\
\hline
\end{tabular}

${ }^{\mathrm{a}} \mathrm{Au} @ \mathrm{TiO}_{2} / \mathrm{MCM}-22(\mathrm{PR})$ (repeated use four times). ${ }^{\mathrm{b}}$ Loading efficiency $=$ Actual Au $* \mathrm{~m}$ (catalyst) $/ \mathrm{No}-$ minal $\mathrm{Au}^{*} 1.00$ (1.00: theoretical mass of the catalyst).

enhance the loading efficiency of Au significantly, compared with deposition precipitation method. The gold loading on $\mathrm{Au} @ \mathrm{TiO}_{2} / \mathrm{MCM}-22$ (PR) doesn't alter basically, even after being utilized four times (Table 2, Entry 5 and 9). Nominal $\mathrm{Au}$ raises the $\mathrm{Au}$ loading but obviously reduces the loading efficiency (Table 2, Entry 3, 4, 5 and 7). This may be the result of deficient illumination time. Perhaps because of the loss of the support during preparation, the loading efficiency exceeds 100\% (Table 2, Entry 3 and 4). With the growth of illumination time, the loading efficiency is also improved (Table 2, Entry 6, 7 and 8), which indicates that the ample illumination time could achieve gold load entirely.

\subsubsection{XRD Analysis}

The X-ray diffraction (XRD) patterns of $\mathrm{TiO}_{2} / \mathrm{MCM}-22$, Au@TiO $/ \mathrm{MCM}-22$ (DP) and $\mathrm{Au} @ \mathrm{TiO}_{2} / \mathrm{MCM}-22(\mathrm{PR})$ are shown in Figure 1. It is obvious that all the samples have some similar peaks. The peaks at $2 \theta=25.3^{\circ}, 38.2^{\circ}, 48.1^{\circ}, 53.5^{\circ}$, $55.1^{\circ}, 62.7^{\circ}, 68.8^{\circ}, 70.3^{\circ}$ and $75.8^{\circ}$ can be indexed to crystallite planes of (101), (004), (200), (105), (211), (204), (116), (220) and (215), respectively, which are ascribed to the anatase- $\mathrm{TiO}_{2}$ (JCPDS card No. 21-1272) [27]. The diffraction peaks at $2 \theta$ of $38.3^{\circ}, 44.4^{\circ}, 64.6^{\circ}$ and $77.6^{\circ}$ (Figure $1(\mathrm{c})$ and Figure $1(\mathrm{~d})$ ) are corresponding to (111), (200), (220), (311) Au plane, respectively, according to JCPDS card No. 76-1082 [28]. Notably, no typical diffraction peaks belonging to the $\mathrm{Au}$ are observed in the Au@TiO $/ \mathrm{MCM}-22$ (DP) nanocomposites. The reason can be 


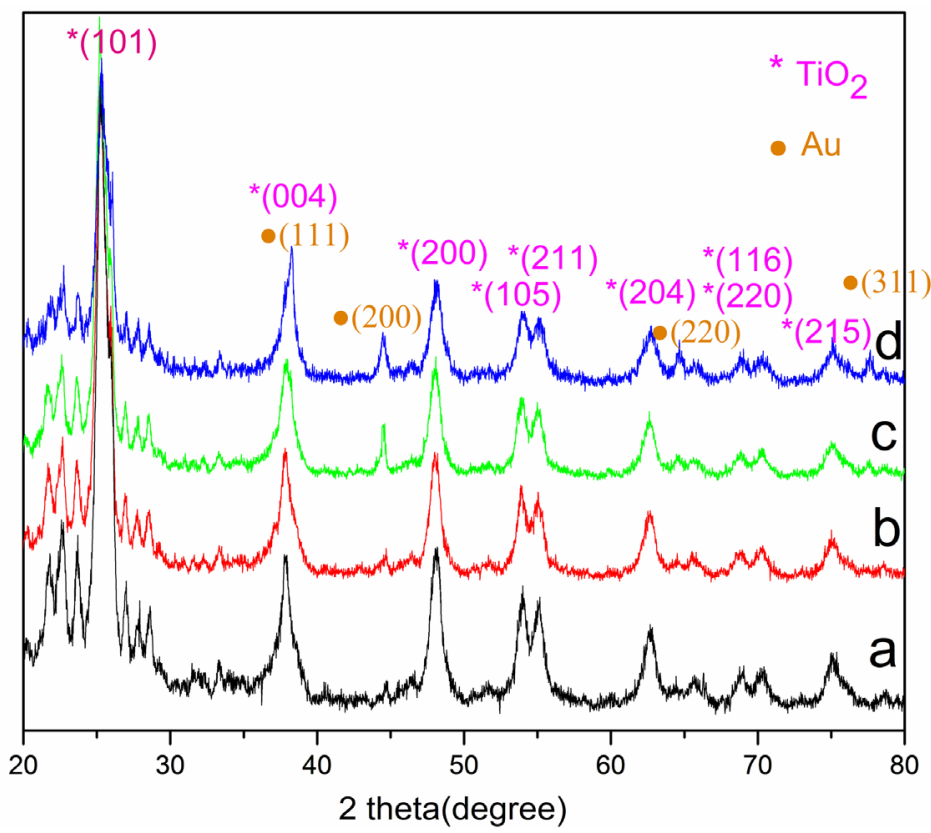

Figure 1. X-ray diffraction pattern of samples. (a) $\mathrm{TiO}_{2} / \mathrm{MCM}-22$; (b) $\mathrm{Au} @ \mathrm{TiO}_{2} / \mathrm{MCM}-22$ (DP); (c) Au@TiO $/ \mathrm{MCM}-22$ (PR); (d) $\mathrm{Au} @ \mathrm{TiO}_{2} /$ MCM-22 (PR) (repeated use four times). Au: $0.5 \mathrm{wt} \%$.

ascribed to the poor weight loading of metal nanoparticles on the $\mathrm{TiO}_{2} / \mathrm{MCM}-22$ by deposition precipitation. In particular, after being used for four times, the $\mathrm{Au} @ \mathrm{TiO}_{2} / \mathrm{MCM}-22$ (PR) sample still exhibits the typical signals of $\mathrm{Au}$, which is in accordance with the ICP-AES result.

\subsubsection{FT-IR Spectra}

Figure 2 shows the FT-IR spectra of the prepared catalysts. It can be seen that there are strong absorption bands at 3440 and $1630 \mathrm{~cm}^{-1}$, which can be assigned to stretching vibration of $-\mathrm{OH}$ of adsorbed water and the vibration of $\mathrm{Si}-\mathrm{O}-\mathrm{H}$ bond [29], respectively. The stretching vibration of Si-O-Si is the cause of bands position around 460 and $1080 \mathrm{~cm}^{-1}$ [30]. Two additional absorption peaks at 965 and $557 \mathrm{~cm}^{-1}$ are attributed to the vibration of the newly-formed Si-O-Ti bond in the spectrum of $\mathrm{TiO}_{2} / \mathrm{MCM}-22$ and $\mathrm{Au} @ \mathrm{TiO}_{2} / \mathrm{MCM}-22$ (PR) [31] [32] which indicate that the $\mathrm{TiO}_{2}$ has doped on the framework of MCM-22.

\subsubsection{TEM Images}

TEM images and Au nanoparticles size distribution histograms of prepared gold catalysts are shown in Figure 3. The gold nanoparticles are evident as small dark spots, while the $\mathrm{TiO}_{2} / \mathrm{MCM}-22$ substrate is brighter and larger. Apparently, gold assembles together on MCM-22, and the diameter range of gold particles is rather broad (Figure 3(a)). The Au@TiO $/ \mathrm{MCM}-22$ (DP) sample shows that modifying MCM-22 with $\mathrm{TiO}_{2}$ could decrease the loaded gold nanoparticles size (6 $10 \mathrm{~nm}$ ) remarkably (Figure 3(b)). Au nanoparticles are successfully immobilized on the $\mathrm{TiO}_{2} / \mathrm{MCM}-22$ with a diameter around 5 - $9 \mathrm{~nm}$ (Figure 3(c)). After being utilized four times, the $\mathrm{Au} @ \mathrm{TiO}_{2}-\mathrm{MCM}-22$ (PR) still maintains the original 


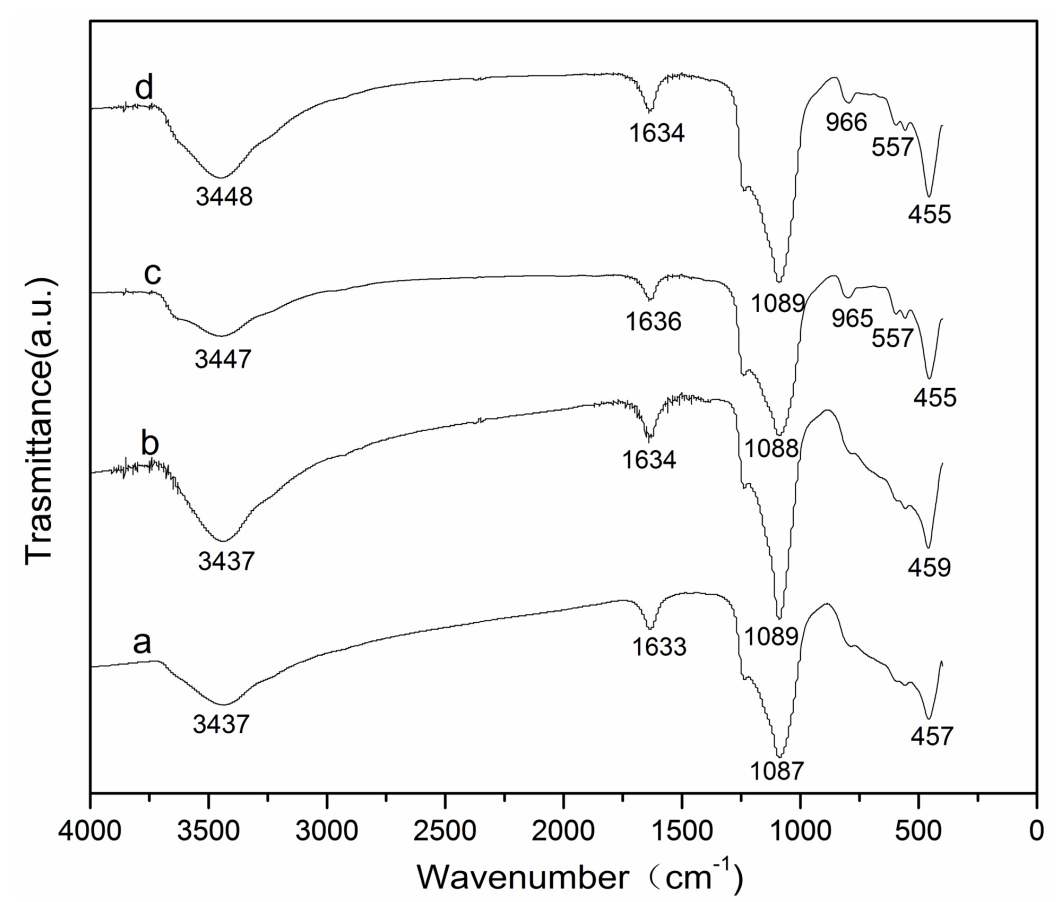

Figure 2. FT-IR spectra of samples. (a) MCM-22; (b) Au/MCM-22; (c) $\mathrm{TiO}_{2} /$ MCM-22; (d) Au@TiO $/$ MCM-22 (PR). Au: 0.5 wt\%.

morphology, which suggests that the gold nanoparticles load on the support stably (Figure $3(\mathrm{~d})$ ). Therefore, photocatalytic direct reduction is an effective method to obtain small size, well dispersion and stable structure nanoparticles.

\subsubsection{UV-Vis Spectra}

UV-visible spectroscopy is an effective method for characterizing the composition and structure of catalysts. Figure 4 shows the UV-vis spectra of $M C M / 22$, Au/MCM-22, Au@TiO $/$ MCM-22 (DP) and Au@TiO $/$ MCM-22 (PR). Generally, a broad absorption band in the visible region around $520 \mathrm{~nm}$ is typical for the surface plasma resonance (SPR) of nano-sized gold [33]. Samples MCM-22 and $\mathrm{TiO}_{2} / \mathrm{MCM}-22$ exhibit featureless spectrum because of the absence of gold. It was reported that with the increase of Au particle size, the SPR peak shifts to longer wavelength or intensifies at longer wavelength [34] [35], that is, the original peak became broader due to the coupling of the individual surface Plasmon of nanoparticles in the aggregated structure [36] [37]. Thus, it is suggestion that the loading of the gold nanoparticles is $\mathrm{Au} @ \mathrm{TiO}_{2} / \mathrm{MCM}-22(\mathrm{PR})>\mathrm{Au} / \mathrm{TiO}_{2} /$ MCM-22 (DP) > Au/MCM-22, perfectly matching the ICP-AES result. An obvious absorption peak at $330 \mathrm{~nm}$ can be found in the spectrum of samples $c, d$ and e, which is attributed to the extra-framework $\mathrm{TiO}_{2}[38]$ and indicates that $\mathrm{TiO}_{2}$ has doped on the support successfully.

\subsection{Catalytic Oxidation of Cyclohexane}

The catalytic performances of the above catalysts were investigated for cyclohexane oxidation. The blank experiment was carried out under the same reac- 

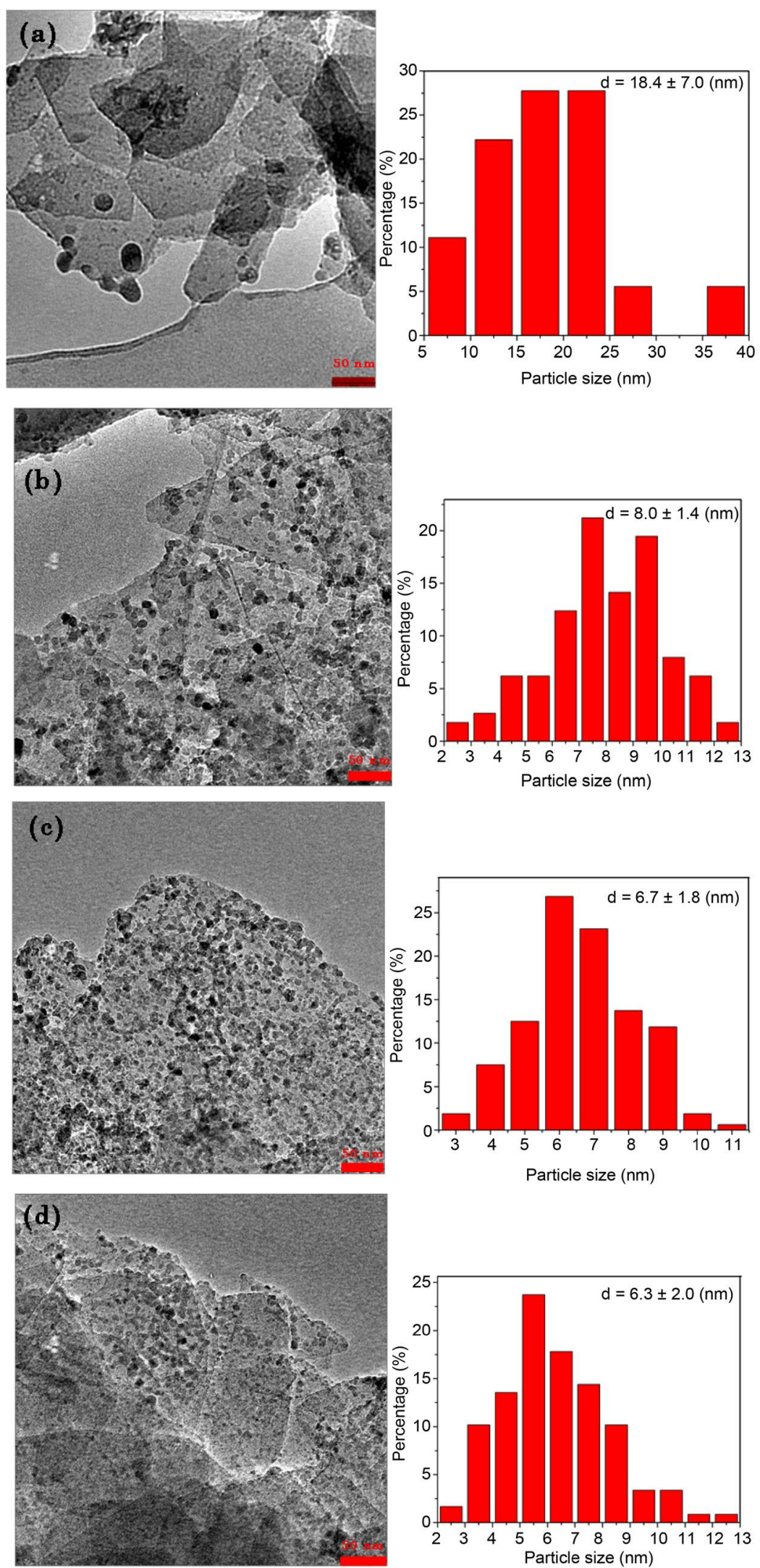

Figure 3. TEM images of catalysts. (a) Au/MCM-22 (DP); (b) Au@TiO $/ \mathrm{MCM}$ 22 (DP); (c) $\mathrm{Au} @ \mathrm{TiO}_{2} / \mathrm{MCM}-22$ (PR); (d) $\mathrm{Au} @ \mathrm{TiO}_{2} / \mathrm{MCM}-22$ (PR) (repeated use four times). Au: $0.5 \mathrm{wt} \%$. 


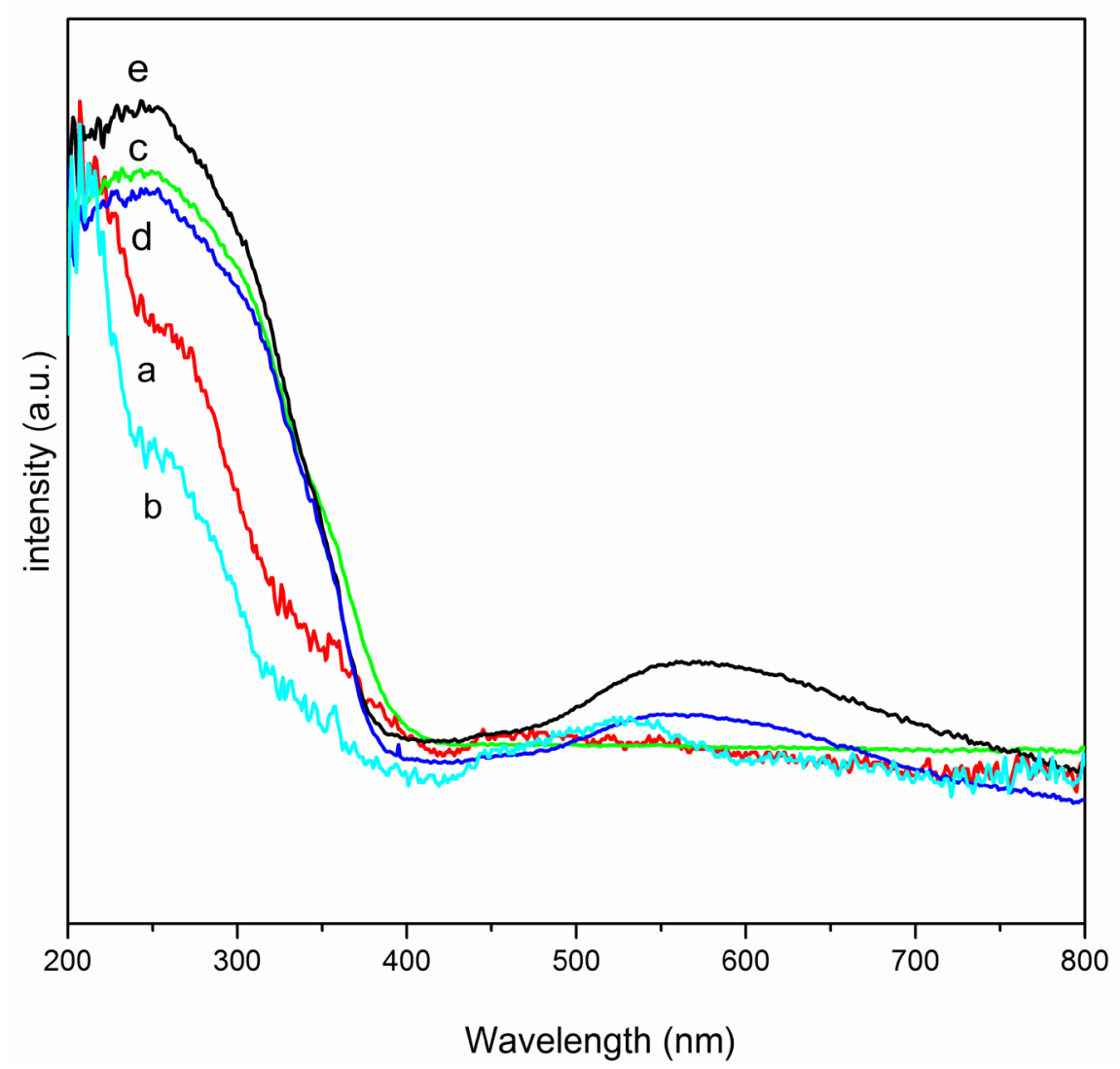

Figure 4. UV-visible spectra of samples. (a) MCM-22; (b) Au/MCM-22; (c) $\mathrm{TiO}_{2} /$ MCM-22; (d) Au@TiO $2 /$ MCM-22 (DP); (e) Au@TiO $/$ MCM-22 (PR). Au: 0.5 wt\%.

Table 3. The results of cyclohexane oxidation over different catalysts ${ }^{\mathrm{a}}$.

\begin{tabular}{|c|c|c|c|c|c|c|c|}
\hline \multirow[b]{2}{*}{ Entry } & \multirow[b]{2}{*}{ Catalyst } & \multirow{2}{*}{$\begin{array}{c}\text { Conversion } \\
(\%)\end{array}$} & \multirow{2}{*}{$\begin{array}{c}\text { Total } \\
\text { selectivity } \\
(\%)\end{array}$} & \multicolumn{4}{|c|}{ Product selectivity $(\%)^{\mathrm{b}}$} \\
\hline & & & & K & A & СHHP & Others \\
\hline 1 & Blank & 4.05 & 81.26 & 43.71 & 20.04 & 17.51 & 18.74 \\
\hline 2 & MCM-22 & 6.78 & 74.78 & 29.92 & 25.15 & 19.71 & 25.22 \\
\hline 3 & $\mathrm{TiO}_{2} / \mathrm{MCM}-22$ & 7.27 & 77.11 & 31.13 & 26.99 & 18.99 & 22.89 \\
\hline 4 & $\mathrm{Au} / \mathrm{MCM}-22$ & 9.38 & 86.50 & 35.61 & 34.64 & 16.25 & 13.50 \\
\hline 5 & $\begin{array}{c}\mathrm{Au} @ \mathrm{TiO}_{2} / \mathrm{MCM}-22 \\
\text { (DP) }\end{array}$ & 10.74 & 86.22 & 35.24 & 33.90 & 17.08 & 13.78 \\
\hline 6 & $\begin{array}{c}\mathrm{Au} @ \mathrm{TiO}_{2} / \mathrm{MCM}-22 \\
\text { (PR) }\end{array}$ & 11.45 & 90.72 & 38.40 & 38.22 & 14.10 & 9.28 \\
\hline
\end{tabular}

${ }^{\mathrm{a} R e a c t i o n}$ conditions: cyclohexane $(100 \mathrm{~mL})$, catalyst $(0.08 \mathrm{~g})$, TBHP $(0.4 \mathrm{~g})$, pressure of $\mathrm{O}_{2}(1.0 \mathrm{MPa})$, temperature $(423 \mathrm{~K})$, reaction time $(1.0 \mathrm{~h}) .{ }^{\mathrm{b}} \mathrm{K}$ : cyclohexanone; A: cyclohexanol; CHHP: cyclohexyl hydroperoxide; Others: acid and ester. Au: $0.5 \mathrm{wt} \%$.

tion conditions. All the results are listed in Table 3. It is obvious that the reaction proceeds spontaneously (Table 3, Entry 1 ) and MCM-22 increases the conversion slightly at the cost of selectivity (Table 3, Entry 2). After $\mathrm{TiO}_{2}$ was deposited on MCM-22, the catalytic activity of $\mathrm{TiO}_{2} / \mathrm{MCM}-22$ was improved because of the subsidiarity of $\mathrm{TiO}_{2}$ (Table 3, Entry 2 and 3). The prepared gold catalysts 
remarkably promote conversion and selectivity of cyclohexane oxidation simultaneously (Table 3, Entry 4 to 6), which confirms that the Au nanoparticles play an essential role in cyclohexane oxidation. Among all the gold catalysts, the $\mathrm{Au} @ \mathrm{TiO}_{2} / \mathrm{MCM}-22$ (PR) exhibits the best catalytic performance for the oxidation of cyclohexane, in respect of conversion and selectivity (Table 3, Entry 6). Remarkable differences can be observed in TOF of cyclohexanol oxidation catalyzed by different gold catalysts (Table 4). The nano-structured Au@ $\mathrm{TiO}_{2} /$ MCM-22 (PR) exhibits extremely higher TOF than the reported gold catalysts [21] [39] [40]. Experiment results also show that the TOF become higher with a decrease in the amount of Au (Table 4). There are three main factors which can explain the excellent catalytic performance. Firstly, the synergistic effect between nano $\mathrm{Au}$ and nano $\mathrm{TiO}_{2}$ plays a vital role. The interaction between the gold and the $\mathrm{TiO}_{2}$ leads to the gold becoming electron-rich [41]. With the help of $\mathrm{TiO}_{2}$, gold could activate oxygen more effectively. The outstanding oxygen storage capacity of $\mathrm{TiO}_{2}$ will be beneficial to the catalytic performance of nano-Au@TiO catalyst for cyclohexane oxidation. Secondly, the small particle size and even size distribution is another major reason for the prominent catalytic results. Thirdly, molecular sieve provides nano-Au@ $\mathrm{TiO}_{2}$ with high specific surface area place. Additionally, $\mathrm{TiO}_{2}$ is a kind of reducible metal oxide that is able to store and release oxygen under oxygen rich and lean conditions, respectively [42]. It is indicated that the complex nano-structured catalyst Au@ $\mathrm{TiO}_{2} / \mathrm{MCM}-22$ exhibits extremely higher TOF than the reported gold catalysts, although the catalytic performance of $\mathrm{Au} @ \mathrm{TiO}_{2} / \mathrm{MCM}-22$ prepared by photocatalytic reduction method is slightly superior to that of prepared by deposition precipitation method.

Table 4. TOF of different gold catalysts.

\begin{tabular}{|c|c|c|c|}
\hline Catalyst & Au content (wt\%) & TOF $^{\mathrm{k}}$ & Reference \\
\hline $\mathrm{Au} @ \mathrm{TiO}_{2} / \mathrm{MCM}-22(\mathrm{DP})^{\mathrm{a}}$ & 0.5 & 48,889 & This work \\
\hline $\mathrm{Au} @ \mathrm{TiO}_{2} / \mathrm{MCM}-22(\mathrm{PR})^{\mathrm{b}}$ & 0.5 & 52,121 & This work \\
\hline $\mathrm{Au} @ \mathrm{TiO}_{2} / \mathrm{MCM}-41^{\mathrm{c}}$ & 0.5 & 4503 & [29] \\
\hline $\mathrm{Au} / \mathrm{ZSM}-5^{\mathrm{d}}$ & 0.51 & 3096 & [39] \\
\hline $\mathrm{Au} / \mathrm{Al}_{2} \mathrm{O}_{3}{ }^{\mathrm{e}}$ & 0.6 & 4508 & [21] \\
\hline $\mathrm{Au} / \mathrm{MCM}-41^{\mathrm{f}}$ & 0.4 & 4550 & {$[40]$} \\
\hline $\mathrm{Au} @ \mathrm{TiO}_{2} / \mathrm{MCM}-22(\mathrm{PR})^{\mathrm{g}}$ & 0.1 & 271,529 & This work \\
\hline $\mathrm{Au} @ \mathrm{TiO}_{2} / \mathrm{MCM}-41(\mathrm{PR})^{\mathrm{h}}$ & 0.1 & 28,854 & [29] \\
\hline $\mathrm{Au} / \mathrm{Al}_{2} \mathrm{O}_{3}{ }^{\mathrm{i}}$ & 0.2 & 16,136 & [21] \\
\hline $\mathrm{Au} / \mathrm{TiO}_{2} / \mathrm{SiO}_{2}{ }^{j}$ & 0.1 & 9723 & [22] \\
\hline
\end{tabular}

areaction conditions: cyclohexane $100 \mathrm{~mL}$, catalyst $0.08 \mathrm{~g}, 423 \mathrm{~K}, 1.0 \mathrm{Mpa} \mathrm{O}, 1 \mathrm{~h}$. ${ }^{\text {b }}$ reaction conditions: cyclohexane $100 \mathrm{~mL}$, catalyst $0.08 \mathrm{~g}, 423 \mathrm{~K}, 1.0 \mathrm{MPa} \mathrm{O}_{2}, 1 \mathrm{~h}$. 'reaction conditions: cyclohexane $100 \mathrm{~mL}$, catalyst $0.02 \mathrm{~g}, 423 \mathrm{~K}, 1.0 \mathrm{Mpa} \mathrm{O}, 2.5 \mathrm{~h}$. ${ }^{\mathrm{r}}$ reaction conditions: cyclohexane $2 \mathrm{~mL}$, catalyst $0.005 \mathrm{~g}, 423 \mathrm{~K}, 1.0 \mathrm{MPa}$ $\mathrm{O}_{2}, 3 \mathrm{~h}$. ${ }^{\mathrm{e}}$ reaction conditions: cyclohexane $20 \mathrm{~mL}$, catalyst $0.005 \mathrm{~g}, 423 \mathrm{~K}, 1.5 \mathrm{MPa} \mathrm{O}_{2}, 3 \mathrm{~h}$. ${ }^{\mathrm{f}}$ reaction conditions: cyclohexane $2 \mathrm{~mL}$, catalyst $0.005 \mathrm{~g}, 423 \mathrm{~K}, 1.0 \mathrm{MPa} \mathrm{O}_{2}, 6$ h. ${ }^{\mathrm{g}}$ reaction conditions: cyclohexane $100 \mathrm{~mL}$, catalyst $0.08 \mathrm{~g}, 423 \mathrm{~K}, 1.0 \mathrm{Mpa} \mathrm{O}_{2}, 1 \mathrm{~h}$. ' reaction conditions: cyclohexane $100 \mathrm{~mL}$, catalyst $0.08 \mathrm{~g}, 423 \mathrm{~K}, 1.0$ $\mathrm{MPa} \mathrm{O}_{2}, 1 \mathrm{~h}$. 'reaction conditions: cyclohexane $20 \mathrm{~mL}$, catalyst $0.05 \mathrm{~g}, 423 \mathrm{~K}, 1.5 \mathrm{Mpa} \mathrm{O}_{2}, 3 \mathrm{~h}$. ${ }^{\mathrm{j}}$ reaction conditions: cyclohexane $20 \mathrm{~mL}$, catalyst $0.05 \mathrm{~g}, 423 \mathrm{~K}, 1.5 \mathrm{MPa} \mathrm{O}_{2}, 1 \mathrm{~h}$. ${ }^{\mathrm{k}}$ calculated by moles of cyclohexane converted per mole of Au per hour. 


\subsection{Recyclability Tests of the Prepared Catalyst}

The recyclability tests were performed to evaluate the reused ability and stability of $\mathrm{Au} @ \mathrm{TiO}_{2} / \mathrm{MCM}-22$ (PR) in cyclohexane oxidation. At completion of each stage, the products were analyzed and the catalyst was recovered by filtration, thoroughly washed in ethanol, dried at $255 \mathrm{~K}$, and then reused for a new set of cyclohexane oxidation experiment. The results in Figure 5 show that there is little fluctuation of conversion or selectivity, namely, Au@TiO $/$ MCM-22 (PR) performs good recyclability. We believe that the SMSI between $\mathrm{Au}$ and $\mathrm{TiO}_{2}$ largely prevented the agglomeration of active sites during the oxidation reaction [43].

\section{Conclusion}

In summary, a novel gold nano-catalyst with nano-structured $\mathrm{Au} @ \mathrm{TiO}_{2}$ has been successfully prepared. Nano-gold is immobilized on the nano- $\mathrm{TiO}_{2}$ layer which is spread on the microporous molecular sieve MCM-22. Characterized results show that gold nanoparticles are immobilized on the substrate with small size $(5-9 \mathrm{~nm})$ and uniform dispersion. The complex nano-structured $\mathrm{Au} @ \mathrm{TiO}_{2} / \mathrm{MCM}-22$ exhibits enhanced catalytic activity for cyclohexane oxidation. The catalytic performance of $\mathrm{Au} @ \mathrm{TiO}_{2} / \mathrm{MCM}-22$ prepared by photocatalytic reduction method is slightly superior to that of prepared catalyst by deposition precipitation. The outstanding catalytic performance could attribute to the synergistic effects of $\mathrm{Au}$ and $\mathrm{TiO}_{2}$ in the complex nano-structured $\mathrm{Au} @ \mathrm{TiO}_{2} / \mathrm{MCM}-22$. The as-synthesized catalyst is chemically and mechanically robust and can be easily separated and reused. Supported noble metal nanoparticles catalysts (Pd, Pt, Ru, etc.) with the complex nano-structured ${\mathrm{Me} @ \mathrm{TiO}_{2}}_{2}$

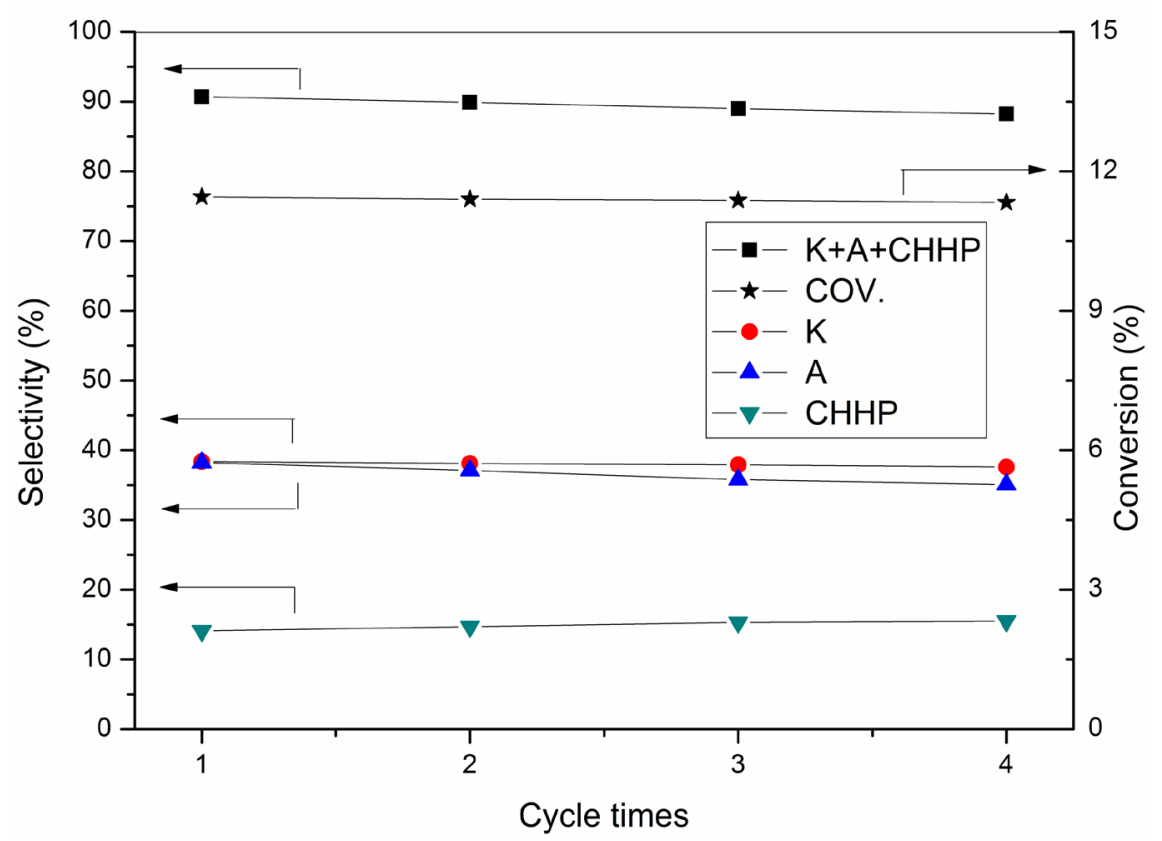

Figure 5. Effect of regeneration time on selective oxidation of cyclohexane. 
could also be high efficient and be applied to different reaction systems. Recently, our group finds that nano- $\mathrm{Pd@} \mathrm{TiO}_{2}$ exhibits remarkably catalytic performance for hydrogenation of phenol under mild condition. We will also implement research on the nano-struc-ture $\mathrm{Me@MO} \mathrm{M}_{\mathrm{x}}\left(\mathrm{MO}_{\mathrm{x}}\right.$ : metal oxides, such as $\mathrm{CeO}_{2}, \mathrm{ZnO}, \mathrm{ZrO}_{2}$, etc.). The relative results will be revealed subsequently.

\section{Acknowledgements}

We gratefully acknowledge the National Natural Science Foundation of China (No. 21676227) and the Project supported by Hunan Provincial Natural Science Foundation of China (No. 09JJ3021) for the financial supports to the present work.

\section{References}

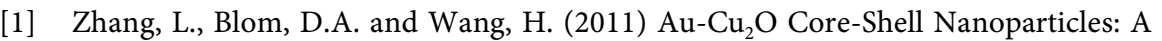
Hybrid Metal-Semiconductor Heteronanostructure with Geometrically Tunable Optical Properties. Chemistry of Materials, 23, 4587-4598. https://doi.org/10.1021/cm202078t

[2] Goodman, D.W. (2005) “Catalytically Active Au on Titania:" Yet Another Example of a Strong Metal Support Interaction (SMSI)? Catalysis Letters, 99, 1-4. https://doi.org/10.1007/s10562-004-0768-2

[3] Costi, R., Saunders, A.E. and Banin, U. (2010) Colloidal Hybrid Nanostructures: A New Type of Functional Materials. Angewandte Chemie International Edition, 49, 4878-4897. https://doi.org/10.1002/anie.200906010

[4] Cortie, M.B. and McDonagh, A.M. (2011) Synthesis and Optical Properties of Hybrid and Alloy Plasmonic Nanoparticles. Chemical Reviews, 111, 3713-3735. https://doi.org/10.1021/cr1002529

[5] Carbone, L. and Cozzoli, P.D. (2010) Colloidal Heterostructured Nanocrystals: Synthesis and Growth Mechanisms. Nano Today, 5, 449-493. https://doi.org/10.1016/j.nantod.2010.08.006

[6] Fu, Q. and Wagner, T. (2007) Interaction of Nanostructured Metal Overlayers with Oxide Surfaces. Surface Science Reports, 62, 431-498. https://doi.org/10.1016/j.surfrep.2007.07.001

[7] Maier, J. (2005) Nanoionics: Ion Transport and Electrochemical Storage in Confined Systems. Nature Materials, 4, 805-815. https://doi.org/10.1038/nmat1513

[8] Diebold, U. (2003) The Surface Science of Titanium Dioxide. Surface Science Reports, 48, 53-229. https://doi.org/10.1016/S0167-5729(02)00100-0

[9] Højrup-Hansen, K., Ferrero, S. and Henry, C.R. (2004) Nucleation and Growth Kinetics of Gold Nanoparticles on MgO (1 000 ) Studied by UHV-AFM. Applied Surface Science, 226, 167-172. https://doi.org/10.1016/j.apsusc.2003.11.017

[10] Al-Abadleh, H.A. and Grassian, V.H. (2003) Oxide Surfaces as Environmental Interfaces. Surface Science Reports, 52, 63-161. https://doi.org/10.1016/j.surfrep.2003.09.001

[11] Chen, S. and Nickel, U. (1996) Synthesis of Hybrid Metal-Semiconductor Ultrafine Particles. Photochemical Deposition of Silver on a ZnO Colloid Surface. Journal of the Chemical Society, Faraday Transactions, 92, 1555-1562. https://doi.org/10.1039/FT9969201555

[12] Christy, A.J. and Umadevi, M. (2012) Synthesis and Characterization of Monodis- 
persed Silver Nanoparticles. Advances in Natural Sciences. Nanoscience and Nanotechnology, 3, Article ID: 035013.

[13] Tauster, S.J., Fung, S.C. and Garten, R.L. (1978) Strong Metal-Support Interactions. Group 8 Noble Metals Supported on Titanium Dioxide. Journal of the American Chemical Society, 100, 170-175. https://doi.org/10.1021/ja00469a029

[14] Tauster, S.J., Fung, S.C., Baker, R.T.K. and Horsley, J.A. (1981) Strong Interactions in Supported-Metal Catalysts. Science, 211, 1121-1125. https://doi.org/10.1126/science.211.4487.1121

[15] Li, Y.Z., Fan, Y.N., Yang, H.P., Xu, B.L., Feng, L.X., Yang, M.F. and Chen, Y. (2003) Strong Metal-Support Interaction and Catalytic Properties of Anatase and Rutile Supported Palladium Catalyst $\mathrm{Pd} / \mathrm{TiO}_{2}$. Chemical Physics Letters, 372, 160-165. https://doi.org/10.1016/S0009-2614(03)00383-X

[16] Weerachawanasak, P., Praserthdam, P., Arai, M. and Panpranot, J. (2008) A Comparative Study of Strong Metal-Support Interaction and Catalytic Behavior of Pd Catalysts Supported on Micron- and Nano-Sized $\mathrm{TiO}_{2}$ in Liquid-Phase Selective Hydrogenation of Phenylacetylene. Journal of Molecular Catalysis A: Chemical, 279, 133-139. https://doi.org/10.1016/j.molcata.2007.10.006

[17] Vayenas, C.G., Brosda, S. and Pliangos, C. (2003) The Double-Layer Approach to Promotion, Electrocatalysis, Electrochemical Promotion, and Metal-Support Interactions. Journal of Catalysis, 216, 487-504. https://doi.org/10.1016/S0021-9517(02)00127-6

[18] Fu, Q., Wagner, T., Olliges, S. and Carstanjen, H.-D. (2005) Metal-Oxide Interfacial Reactions: Encapsulation of $\mathrm{Pd}_{\text {on }} \mathrm{TiO}_{2}$ (110). The Journal of Physical Chemistry $B$, 109, 944-951. https://doi.org/10.1021/jp046091u

[19] Schuchardt, U., Cardoso, D., Sercheli, R., Pereira, R., de Cruz, R.S., Guerreiro, M.C., Mandelli, D., Spinace, E.V. and Fires, E.L. (2001) Cyclohexane Oxidation Continues to Be a Challenge. Applied Catalysis A: General, 211, 1-17. https://doi.org/10.1016/S0926-860X(01)00472-0

[20] Weissermel, K. and Arpe, H.-J. (2003) Industrial Organic Chemistry. 4th Edition, Wiley-VCH, Weinheim. https://doi.org/10.1002/9783527619191

[21] Xu, L.X., He, C.H., Zhu, M.Q. and Fang, S. (2007) A Highly Active $\mathrm{Au} / \mathrm{Al}_{2} \mathrm{O}_{3}$ Catalyst for Cyclohexane Oxidation Using Molecular Oxygen. Catalysis Letters, 114, 202-205. https://doi.org/10.1007/s10562-007-9058-0

[22] Xu, L.X., He, C.H., Zhu, M.Q., Wu, K.J. and Lai, Y.L. (2007) Silica-Supported Gold Catalyst Modified by Doping with Titania for Cyclohexane Oxidation. Catalysis Letters, 118, 248-253. https://doi.org/10.1007/s10562-007-9178-6

[23] Xu, L.X., He, C.H., Zhu, M.Q., Wu, K.J. and Lai, Y.L. (2008) Surface Stabilization of Gold by Sol-Gel Post-Modification of Alumina Support with Silica for Cyclohexane Oxidation. Catalysis Communications, 9, 816-820.

https://doi.org/10.1016/j.catcom.2007.09.005

[24] Wu, Y.J., Ren, X.Q., Lu, Y.D. and Wang, J. (2008) Rapid Synthesis of Zeolite MCM22 by Acid-Catalyzed Hydrolysis of Tetraethylorthosilicate. Materials Letters, 62, 317-319. https://doi.org/10.1016/j.matlet.2007.05.026

[25] Pan, X.Y. and Xu, Y.-J. (2013) Fast and Spontaneous Reduction of Gold Ions over Oxygen-Vacancy-Rich $\mathrm{TiO}_{2}$ : A Novel Strategy to Design Defect-Based Composite Photocatalyst. Applied Catalysis A: General, 459, 34-40.

https://doi.org/10.1016/j.apcata.2013.04.007

[26] Li, L., Jin, C., Wang, X.C., Ji, W.J., Pan, Y., van der Knaap, T., van der Stoel, R. and $\mathrm{Au}$, C.T. (2009) Cyclohexane Oxidation over Size-Uniform Au Nanoparticles (SBA15 Hosted) in a Continuously Stirred Tank Reactor Under Mild Conditions. Cataly- 
sis Letters, 129, 303-311. https://doi.org/10.1007/s10562-009-9853-x

[27] Yan, W.F., Chen, B., Mahurin, S.M., Schwartz, V., Mullins, D.R., Lupini, A.R., Pennycook, S.J., Dai, S. and Overbury, S.H. (2005) Preparation and Comparison of Supported Gold Nanocatalysts on Anatase, Brookite, Rutile, and P25 Polymorphs of $\mathrm{TiO}_{2}$ for Catalytic Oxidation of CO. The Journal of Physical Chemistry B, 109, 10676-10685. https://doi.org/10.1021/jp044091o

[28] Ismail, A.A., Hakki, A. and Bahnemann, D.W. (2012) Mesostructure Au/TiO $\mathrm{Ta}_{2} \mathrm{Na}$ nocomposites for Highly Efficient Catalytic Reduction of p-Nitrophenol. Journal of Molecular Catalysis A: Chemical, 358, 145-151. https://doi.org/10.1016/j.molcata.2012.03.009

[29] Zhou, J.C., Yang, X.F., Wang, Y.Q. and Chen, W.J. (2014) An Efficient Oxidation of Cyclohexane over Au TiO $/$ MCM-41 Catalyst Prepared by Photocatalytic Reduction Method Using Molecular Oxygen as Oxidant. Catalysis Communications, 46, 228 233. https://doi.org/10.1016/j.catcom.2013.12.026

[30] Izutsu, H., Nair, P.K., Maeda, K., Kiyozumi, Y. and Mizukami, F. (1997) Structure and Properties of $\mathrm{TiO}_{2}-\mathrm{SiO}_{2}$ Prepared by Sol-Gel Method in the Presence of Tartaric Acid. Materials Research Bulletin, 32, 1303-1311. https://doi.org/10.1016/S0025-5408(97)00106-2

[31] Thangaraj, A., Kumar, R., Mirajkar, S.P. and Ratnasamy, P. (1991) Catalytic Properties of Crystalline Titanium Silicalites I. Synthesis and Characterization of Titanium-Rich Zeolites with MFI Structure. Journal of Catalysis, 130, 1-8. https://doi.org/10.1016/0021-9517(91)90086-J

[32] Tuel, A. (1996) Crystallization of Titanium Silicalite-1 (TS-1) from Gels Containing Hexanediamine and Tetrapropylammonium Bromide. Zeolites, 16, 108-117. https://doi.org/10.1016/0144-2449(95)00109-3

[33] Daniel, M.-C. and Astruc, D. (2004) Gold Nanoparticles: Assembly, Supramolecular Chemistry, Quantum-Size-Related Properties, and Applications toward Biology, Catalysis, and Nanotechnology. Chemical Reviews, 104, 293-346. https://doi.org/10.1021/cr030698+

[34] Wu, P.P., Bai, P., Lei, Z.B., Loh, K.P. and Zhao, X.S. (2011) Gold Nanoparticles Supported on Functionalized Mesoporous Silica for Selective Oxidation of Cyclohexane. Microporous and Mesoporous Materials, 141, 222-230. https://doi.org/10.1016/j.micromeso.2010.11.011

[35] Wu, P.P., Bai, P., Loh, K.P. and Zhao, X.S. (2010) Au Nanoparticles Dispersed on Functionalized Mesoporous Silica for Selective Oxidation of Cyclohexane. Catalysis Today, 158, 220-227. https://doi.org/10.1016/j.cattod.2010.03.027

[36] Fang, J., Cao, S.-W., Wang, Z., Mehdi Shahjamali, M., Loo, S.C.J., Barber, J. and Xue, C. (2012) Mesoporous Plasmonic Au-TiO ${ }_{2}$ Nanocomposites for Efficient Visible-Light-Driven Photocatalytic Water Reduction. International Journal of Hydrogen Energy, 37, 17853-17861. https://doi.org/10.1016/j.ijhydene.2012.09.023

[37] Zhong, Z.Y., Patskovskyy, S., Bouvrette, P., Luong, J.H.T. and Gedanken, A. (2004) The Surface Chemistry of Au Colloids and Their Interactions with Functional Amino Acids. The Journal of Physical Chemistry B, 108, 4046-4052. https://doi.org/10.1021/jp037056a

[38] Wang, M., Zhou, J.C., Mao, G.Y. and Zheng, X.L. (2012) Synthesis of TS-1 from an Inorganic Reactant System and Its Catalytic Properties for Allyl Chloride Epoxidation. Industrial \& Engineering Chemistry Research, 51, 12730-12738. https://doi.org/10.1021/ie202524t

[39] Zhao, R., Ji, D., Lv, G.M., Qian, G., Yan, L., Wang, X.L. and Suo, J.S. (2004) A Highly Efficient Oxidation of Cyclohexane over Au/ZSM-5 Molecular Sieve Catalyst 
with Oxygen as Oxidant. Chemical Communications, 10, 904-905. https://doi.org/10.1039/b315098d

[40] Lü, G.M., Zhao, R., Qian, G., Qi, Y.X., Wang, X.L. and Suo, J.S. (2004) A Highly Efficient Catalyst Au/MCM-41 for Selective Oxidation Cyclohexane Using Oxygen. Catalysis Letters, 97, 115-118. https://doi.org/10.1023/B:CATL.0000038571.97121.b7

[41] Laursen, S. and Linic, S. (2009) Strong Chemical Interactions between Au and OffStoichiometric Defects on $\mathrm{TiO}_{2}$ as a Possible Source of Chemical Activity of Nanosized Au Supported on the Oxide. The Journal of Physical Chemistry C, 113, 66896693. https://doi.org/10.1021/jp810603u

[42] Widmann, D., Liu, Y., Schüth, F. and Behm, R.J. (2010) Support Effects in the AuCatalyzed CO Oxidation-Correlation between Activity, Oxygen Storage Capacity, and Support Reducibility. Journal of Catalysis, 276, 292-305. https://doi.org/10.1016/j.jcat.2010.09.023

[43] Tan, H.T., Chen, Y.T., Zhou, C.M., Jia, X.L., Chen, J., Rui, X.H., Yan, Q.Y. and Yang, Y.H. (2012) Palladium Nanoparticles Supported on Manganese Oxide-CNT Composites for Solvent-Free Aerobic Oxidation of Alcohols: Tuning the Properties of Pd Active Sites Using MnOx. Applied Catalysis B: Environmental, 119-120, 166174. https://doi.org/10.1016/j.apcatb.2012.02.024

Submit or recommend next manuscript to SCIRP and we will provide best service for you:

Accepting pre-submission inquiries through Email, Facebook, LinkedIn, Twitter, etc. A wide selection of journals (inclusive of 9 subjects, more than 200 journals) Providing 24-hour high-quality service User-friendly online submission system Fair and swift peer-review system Efficient typesetting and proofreading procedure Display of the result of downloads and visits, as well as the number of cited articles Maximum dissemination of your research work

Submit your manuscript at: http://papersubmission.scirp.org/

Or contact mrc@scirp.org 